Technical Report

\title{
Ethanol Production from Rice on Radioactively Contaminated Field toward Sustainable Rice Farming
}

\author{
Shinya YoKoYAmA *1, Bintaro IZUMI*2, Kazuo OKI*3 \\ (Received June 1, 2011)
}

\author{
持続的稲作を目指した放射能污染土䁃におけるイネからのエタノール生産 \\ 横山伸也*1，和泉敏太郎*2，沖 一雄*3
}

\begin{abstract}
Radioactive species such as ${ }^{137} \mathrm{Cs}$ were discharged from Fukushima Daiichi Nuclear Power Plant which was severely damaged by the enormous earthquake and tsunami. Cropland has been radioactively contaminated by ${ }^{137} \mathrm{Cs}$ etc. and it seems impossible to plant rice due to the non-suitability for food. According to the reports, ${ }^{177} \mathrm{Cs}$ transferred into the rice from soil is less than $1 \%$ on the average. Therefore, it is expected that the concentration of ${ }^{137} \mathrm{Cs}$ in bioethanol will be well below the tentative restriction value even if bioethanol could be produced from the rice. It is proposed that the rice field should be filled with water to avoid the flow of runoff contaminated by radioactive cesium compounds because they are insoluble in aqueous phase and that bioethanol should be produced from the rice in order to maintain the multifunction of rice field and to continue the agriculture. If rice farming is halted and neglected, agricultural function of rice field as well as local community will be permanently destroyed.
\end{abstract}

\section{Key Words}

Rice, Radioactivity, Cesium, Bioethanol, Sustainability

\section{1. 緒 言}

平成 23 年 3 月 11 日に東北地方の太平洋沿岸での大地震と 津波に加えて，福島県では東京電力福島第一原子力発電所が 被災した。地震により外部電源打よび非常用ディーゼル発電 機が故障し全交流電源が喪失した。このために泠却作業が不 可能になり外部から水を注入した。しかし，格納容器内の圧 力が高まったために，内部のガスを外部へ排気するべント操 作を行ったが，これに伴い放射性を带びた気体が屋外に放出 されることになった。さらに，大地震の翌日 1 号機では原子 炉冷却水峦失による核燃料温度上昇に伴い水素が大量に発生 し水素爆発が起こり，さらに 2 号機と 3 号機の爆発に加えて 4 号機に火災が生じ污染が搪大した。

報道によれば1)，福島県川内村周辺では土壤の放射能が

* 1 Department of Environmental Management Faculty of Environmental and Information Studies, Tottori University of Environmental Studies 1-1-1, Wakabadai-kita, Tottori-shi, Tottori 689-1111, Japan

* 2 NPO of Shimane Bio Ethanol Research Party c/o Corp. Building 15, Chidori-cho, Matsue-shi, Shimane 690-0852, Japan

* 3 Institute of Industrial Science, The University of Tokyo 4-6-1, Komaba, Meguro-ku, Tokyo 153-8505, Japan
$1 \mathrm{~kg}$ 当たり $1526 \mathrm{~Bq}$ と暫定基準值の $5000 \mathrm{~Bq}$ を下回っている にもかかわらず，ほとんどの農家が作付けを諦めているのが 実態である。イネの作付けを放棄すれば二，三年で水田は荒 れ果て，それ以上放置しておくと水田機能を回復することす ら難しい状況になるといわれている。

本提案は，主にセシウム ${ }^{137} \mathrm{Cs}$ により放射能污染された水田 で，手間がかからず肥料も少なくて済む多収穫米を育て，各 地域に小規模なエ夕ノール製造システムを設置してバイオエ タノールを製造してエネルギー用として供するものである。 これまでの報告から土壤中の ${ }^{137} \mathrm{Cs}$ は根から吸収されるが，移 行率は極めて小さく玄米中の蓄積量も小さい2）31。したがっ て，コメから製造したエタノール中の ${ }^{137} \mathrm{Cs}$ 濃度は暫定規制值 を十分にクリアーできると予想される。本提案により放射能

* 1 鳥取環境大学環境情報学部情報マネジメント学科 于 689-1111 鳥取市若葉台北 1-1-1

* 2 特定非営利活法人しまねバイオエタノール研究会 テ 690-0852 島根県松江市千鳥町 15 コープビル

* 3 東京大学生産技術研究所 于 153-8505 東京都目黒区駒場 4-6-1 
污染された土畩は徐々に除染されると共に, 水田が放裹地に ならずにその機能を維持でき農家の生産活動が継続できる。 エタノールの生産, 利用に関して特区のような措置をとるこ とで, 地域の雇用拡大ができ, 次世代の再生可能エネルギー 生産の先端的モデル地区として新産業の創出に貢献し，農業 従事者が将来展望を持つことができる。バイオエタノールを ガソリンに混合利用することにより，県内の石油消費を抑制 でき, 将来の安定的な石油代替燃料の開発につなげられると 考える。

\section{2. 方 策}

土壤の放射能污染の主因は ${ }^{137} \mathrm{Cs}$ であり，ヨウ素の半減期が 8 日であるのに対して約 30 年と長い。したがって，農地を放 置しておくと劣化が進行し事実上農地として使うことが不可 能になるだけではなく営農ができず，経済的にも大きな打撃 を受けることになる。そこで, 放射能污染の危惧から食用米 としてではなく，エネルギー用の稲作をすれば従来どおりの 営農が可能になる。ただし，当然ながら生産されるエ夕ノー ルに許容量以上の放射性物質が含まれないことが求められ， 稲作やエタノール製造過程において必要に応じて放射線の遮 蔽などの対策は必要である。

\section{1 作付け}

耕作中の土壇粉塵などによる内部被爆や作業時の外部被爆 を避けるために，作業の簡略化と常時周辺環境の放射線監視 を行うと共に，農業従事者にフィルムバッジ・積算線量形な どを着用してもらい，放射線従事者に準じた管理を行うこと により被曝線量を十分に管理する。効率を上げるためにでき るだけ農地を集約化することで大規模にし，農作業を無人耕 運機や刈り取り機を導入することが望ましい4)。 ${ }^{137} \mathrm{Cs}$ は体内攝 取したときカリウムと同様の振る舞いをし，筋肉組織に蓄積 して $\beta$ 線による内部被爆が生ずるとされている。体内吸収を 避けるために，水田を乾燥せず農作業を簡素化することが望 まれる。

津村らは，土壤による ${ }^{137} \mathrm{Cs} の$ 固定に及ぼす湛水処理の影響 を調べ, ${ }^{137} \mathrm{Cs}$ は主に固定態と置換態で存在し，水溶性で存在 するのは $1 \%$ 以下であると報告している2)。報道によれば，広 島大学が福島県で行った調査の結果, ${ }^{137} \mathrm{Cs}$ は地表から $5 \mathrm{~cm}$ 以 内に $90 \%$ 留まっており，15 cmでは99\%以上が留まっている と報告されている5)。セシウムは土壤中の粘土と強く結合して 表層に留まっているので深いところにしみ込まない性質があ る。逆に風の影響で表層の土壤が環境中に飛散する恐れがあ るが，湛水状態にすることで飛散を防止できる。いずれにせ よ，水田では不透水層が存在するので，七シウム濃度は容易 には減少しないと思われる。事実，駒村らの研究によれば，水 田における ${ }^{137} \mathrm{Cs}$ の滞留半減時間は $9 \sim 24$ 年と報告されてい る ${ }^{6)}$ 。

水田には灌溉が不可欠であり，灌溉水に放射性物質が混入 してくる可能性は否定できないので循環的な利用を行うこと が望ましいが，できない場合でも放射線量計でモニタリング
しながら水路にゼオライトのような吸着剤を敷設する。天然 ゼオライトは合成ゼオライトやイオン交換樹脂よりもCsを効 率よく除去できると報告されており, コスト面からも有望で ある ${ }^{7)}$

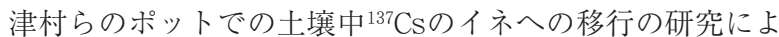
れば，経根吸収される場合は土壤の性質や施肥の種類や量な どにより左右されるが， ${ }^{137} \mathrm{Cs} の 土$ 壤から玄米への移行率は 2.4 $\times 10^{-1} \sim 0.59 \times 10^{-2}$ であった ${ }^{2)}$ 。ただし，この数值はポット 実験の結果であり，かなり過酷な条件で得られたものである。 Tsukada らは実際の田戋から採取した土壤中の ${ }^{137} \mathrm{Cs} の$ 白米部 への平均移行率は $1.6 \times 10^{-3}$ であり，白米に含まれる ${ }^{137} \mathrm{Cs}$ は 玄米に比べて約半分と報告している ${ }^{3)}$ 。IAEAの報告書によれ ば，466検体の土壤からイネへの移行率は最大值が $6.1 \times 10^{-1}$, 最小值が $1.3 \times 10^{-4}$, 平均值が $8.3 \times 10^{-3}$ であった ${ }^{8)}$ 。これら の結果から, 土壤から可食部に移行する ${ }^{137} \mathrm{Cs} の$ 濃度は非常に 小さいと予想できる。

\section{2 エタノール製造}

イネからエタノールを製造するには，モミガラから玄米を 分離した後, 粉砕して液化処理をして糖化しさらに酵素で発 酵する。発酵した後, 蒸留と脱水をしてエタノールを得る。残 渣として発酵残渣と発酵廃液が残る。この全工程において放 射線遮蔽が簡単にできるようにできるだけシンプルな設備に する。すなわち, 液化, 糖化, 発酵などの工程が 1 つの夕ン クで行えるようなシステムにし，例えば $500 \mathrm{kl} \sim 1,000 \mathrm{kl}$ 規 模のシステムを当該地域毎に数ケ所分散設置し，濃度約 $30 \%$ 程度のエタノールを製造して, 蒸留・脱水基地まで運搬して $99.5 \mathrm{v} \%$ 以上の無水エタノールにし，ガソリン混合燃料として 使用する。脱水エレメントには ${ }^{137} \mathrm{Cs}$ 吸着除去できるゼオラ イトを使用して放射性物質がエタノールに入らないようにす る。 ${ }^{137} \mathrm{Cs}$ の沸点は $640^{\circ} \mathrm{C}$ であるが，蒸留・脱水装置内でエ夕 ノール - 水混合物の温度は約 $120^{\circ} \mathrm{C}$ 以下であり Cs が気化する 心配はない。さらに ${ }^{137} \mathrm{Cs}$ 水溶液中で揮発性の化合物を作ら ないとされている。したがって，生成したエタノールには ${ }^{137} \mathrm{Cs}$ が含まれないか, 含まれるとしても土䁃からイネへの移行率 が 1 \%程度であることを考慮すれば，極めて低い濃度である ことが予想される。仮に土壤中の ${ }^{137} \mathrm{Cs}$ 濃度が $5000 \mathrm{~Bq}$ とした 場合は, エタノール中の ${ }^{137} \mathrm{Cs}$ 濃度は $50 \mathrm{~Bq}$ 以下であると期待 できる。

\section{3. 放射性廃物の処理}

イネの副産物であるイナワラとモミガラにも，エタノール 製造の過程で副生する発酵残渣と発酵廃液にも同様に ${ }^{137} \mathrm{Cs}$ 含まれているので，これらは適正に処理する必要がある。通 常は原子力発電所で発生する低レベル放射性廃棄物は発電所 内にある「低レベル放射性廃裹物専用の焼却炉」で焼却して 減容し，ドラム缶詰して青森県六ヶ所村にある設備で地層 処分している。現状では低レベル放射性廃棄物の放射能濃度 基準は設定されておらず，廃棄処分方法，廃棄場所も設定さ れていない。公衆の放射線被曝を極力小さくするためにも，早 
急に関連法律制定が必要である。

本提案の各プロセスで排出されるイナワラ，モミガラに加 えて，発酵残渣や発酵廃液も同様に「低レベル放射性廃棄物 専用の焼却炉」で処分するのが適当と考えられる。なお，こ の焼却炉の排気はセラミックフィルターを使用しており，ご く微小な放射性物質であっても除去できるようになっている。 あるいは，一般的な焼却炉で排気温度を調整しゼオライトを フィルターとして使用して放射性物質を取り除く等の工夫を する。いずれの場合も焼却熱等は，蒸留・脱水基地のエネル ギーとしても利活用が図れる。

\section{4 外部エネルギー源}

エタノール製造では蒸留・脱水工程に熱源としてかなりの エネルギーが使用され，コーンからエタノールを製造する場 合は全体の約 $30 \%$ である ${ }^{9)}$ 。今回の原子力災害では, 周辺の 市町村で家屋等が津波で破壊され，さらに放射能污染されて いる廃棄物は，発電所内で発生する低レベル放射性廃棄物と 同様に扱われるべきものと考えれば，いずれ「低レベル放射 性廃棄物専用の焼却炉」が設置されるものと思われる。放射 能対策が必要になりコスト増になる可能性があるが，廃熱を 利用することも想定できるし，周辺で放射能污染のないある いは基準值以下の場合は，外部のエネルギー源として津波で 破壊された建築廃材や倒木，イナワラ，モミガラなども利用 できる。

\section{3. 課 題}

以上，放射能污染された土壤の修復策として，従来通りイ ネを栽培してこれからエタノールを製造するという希望の持 てる放射能対策の可能性を示した。これを具体的に実現する ためにはいくつかの課題があるので以下に列挙する。

（1）放射能事故という非常事態の中で，福島県の復旧，復興の ために全体あるは一部を特区としてできるだけの支援を する。

（2）今年の作付けを見送った水田に関しては，水田としての 機能を失わないように湛水状態に保持する。

（3）イネの耕作に関しては，被曝を避けるために十分な放射 線監視とできるだけ農業従事者の作業を簡素化し，無人 化，自動化，機械化を図る。

（4）エタノール生産に関しては，全工程が必要に応じて放射 性遮蔽できる連続工程の小型プラントを設計・試作する。 液化·糖化·発酵が単一の夕ンクでできるようにシンプル な構造にする。

（5）放射性廃棄物については「低レベル放射性廃棄物専用の 焼却炉」で処分するなど万全の安全性を図る。

（6）仮に，バイオエタノールが製造された場合は，福島県内を エネルギー特区とし，地産地消とする。なお混合ガソリン 自体を無税にする。また混合比率もE3 でなく海外並みの 混合率を検討する。

\section{4. 結 言}

放射能により污染された田戋を放置せず，イネを作付けし てエタノールを生産することで営農を可能にするシステムを 提案した。畑地の場合は，放射性物質を選択的に吸収する品 種があればいわゆるバイオレメデイエーションにより除染が 可能であるが，田戋は一度稲作を放暂すれば修復が困難であ る。しかし，燃料用エタノールを生産するシステムを構築す ることで稲作の継続が可能になる。

植物による土壇中の放射能污染物質の吸収に関して，特に イネは土壤からの移行率が小さく短期間での除染は難しいと 思われる。逆に，移行率が小さいことからイネに吸収される 放射能污染物質の濃度は低く，これまでの報告例から推定す るとエタノール発酵した場合にエタノールに含まれる放射能 污染物質濃度は暫定規制值以内に収まることが予想される。

5 月 11 日の読売新聞の論点で鈴木元氏は「希望持てる放射 能対策を」の中で，チェルノブイリ事故後は，菜種の中でも 放射性物質の影響の少ない品種を栽培, 精製した油をバイオ 燃料に加工し，菜種から食用油にする過程でも放射性物質を 除去できたとされ，アルコールや砂糖の原料にする麦類など の作付けも推奨されたと報告している10)。畑であれば菜種な り麦なりを栽培すればよいが，福島県の様な水田地帯におい ては水田の機能を生かすには稲作が最も適切と考えられる。

チェルノブイリ事故15 年後の報告によれば，放射能污染さ れた農地の除染として表土を除くという方法はコストがかさ むこと，土壤の肥沃度が失われること，污染土による環境問 題などで不適切とされており, 本提案のような方法が適切と 考える ${ }^{11)}$ 。

わが国の農業は地域社会と深い絆があり，この事故で農業 が立ち行かなくなると，単に営農ができなくなり農産物が生 産できなくなるに止まらず，地域社会そのものが破壊される ことになり地域文化の喪失に結びつく。事故が収束しても土 壤の放射能污染の懸念がなくなるのには10年単位の時間が必 要と思われる。このような事態を避け, 明日の希望へとつな がる放射能対策を目的として，イネからのエタノール生産シ ステムを提案する次第である。もとより経済的にはコス卜高 になるのは明らかではあるが，再生可能エネルギー生産の場 として農業の新しい可能性を秘めて㧍り, 何よりも農業従事 者が誇りを持ち，地域社会が健全に維持できる意義は大きい のではなかろうか。

\section{謝 辞}

本研究は公益財団法人谷川熱技術振興基金の助成により行 われたことを記し，謝意を表する。バイオエタノールの各工 程のエネルギー収支に関しては，(財) エネルギー総合工学研 究所プロジェクト試験研究部の副参事山田富明博士に資料提 供をして頂き懇切にご教示頂いた。記して感謝申し上げる。国 際医療福祉大学の鈴木元教授にはチェルノブイリ事故後の放 射能污染農場の除染について，(独）農業環境技術研究所の谷 山一郎氏にはイネへの放射能物質の移行についての情報をご 提供頂いた。深く感謝申し上げる。 


\section{文 献：References}

1）河北新報，平成 23 年 5 月 23 日

2）津村昭人，駒村美佐子，小林宏信，農業技術研究報告書B, 36, 57-113(1984)

3) Tsukada, H., Hasegawa, J., Hisamatsu, S., Yamasaki, S., J. Environmental Radioactivity, 59, 351-363(2002)

4) Li, M., Imou, K., Wakabayashi, K., Yokoyama, S., Int. J. Agric.\& Biol.Eng., 2(3), 1-16(2009)

$5 ）$ 朝日新聞，平成 23 年 5 月 24 日朝刊

6）駒村美佐子，津村昭人，山口紀子，藤原英司，木方展治， 小平潔，農業環境技術研究所報告，24, 1-21(2006)

7）塩村隆信，小川仁一，今若直人，野田修二，第17回ゼ才 ライト研究発表会予稿集，p. 7(2001)
8) TECHNICAL REPORTS SERIES No.472: Handbook of Parameter Values for the Prediction of Radionuclide Transfer in Terrestrial and Freshwater Environments, International Atomic Energy Agency, Vienna, (2010)

9）山田富明，バイオエタノール製造システムの比較とコスト 評価，バイオ液体燃料，（(株)エヌ・ティー・エス $), p$. 91-114(2007)

10）鈴木元，論点，読売新聞，平成 23 年 5 月 11 日朝刊

11）デビル・G・カベリン他(責任翻訳：鈴木元)，農業におけ る対策；チェルノブイリ事故後 15 年における効率の評 価・その教訓 (2001年キエフ国際会議プロシーディン グ $),($ 国連人道問題調整部，ニューヨーク $)$, p. 118-128 (2001) 